\title{
The Methods Used in Monitoring of Large Dams in Turkey
}

\author{
Haluk BALI ${ }^{*}$, Salih ALCAY ${ }^{2}$ \\ ${ }^{1}$ The General Directorate of State Hydraulic Works, 5. Regional Directorate, 56. Division Office, Kirıkkale, Turkey, \\ ${ }^{2}$ Necmettin Erbakan University, Engineering and Achitecture Faculty, Geomatics Engineering Department, Konya, \\ Turkey.
}

\begin{abstract}
Turkey is a very rich country in terms of water resources. However, in order to use these resources efficiently, water must be stored safely. In this context, the best form of storage is the construction of dams. In our country, large dams, which are among the world's important dams, are being built. Although there are many advantages of large dams, the loss of life and property will be so great in case of a possible deformation or destruction. The fact that dams are under the influence of various forces, as well as being located in the earthquake zone of our country, necessitates continuous monitoring of our dams. Dams are generally monitored using geodetic methods and geotechnical devices. However, mostly details of these two methods are evaluated separately in dam monitoring. Evaluating the results of both methods together is very important for the comprehensive monitoring of the dam and the correct interpretation of possible deformations. In this study, large dams in our country and monitoring studies carried out by using geodetic and geotechnical methods in these dams are given in detail.
\end{abstract}

Key words: Dam, Deformation Monitoring, Geodetic, Geotechnical

\section{Introduction}

In our country, increasingly large and more important dams are being built in order to meet the increasing water and energy needs and to reduce the dependence on foreign energy. The dam construction adventure that started with Çubuk Dam, which was completed in 1936, reached the top level with important dams such as Sarıyar and Gökçekaya in the 1950s, and the dam experience has increased the confidence of engineers and workers in the dam construction with the Keban Dam completed in 1975. Afterwards, important dams such as Karakaya, Oymapinar, Altınkaya and Hasan Ugurlu were built. Atatürk Dam, which was completed in 1992, was the peak of dam engineering. In 2000s, an increase in the number of concrete arch dams is observed. Çine, Ermenek, Ilısu, Deriner dams, whose construction was completed after 2000, and Yusufeli Dam, whose construction is still ongoing, are the pride of our country.

There are mostly examples of embankment and concrete dam types in our country. These dams are at the forefront of the world considering the criteria such as filling volume, height, reservoir capacity, crest length. It is important that dams are constantly monitored to function safely. For this reason, it is crucial to present the current status of dams and their behavior under changeable conditions within an information system. It is particularly important to monitor the large dams and their surroundings with geodetic and geotechnical methods. Geodetic methods include

*Corresponding author: Address: The General Directorate of State Hydraulic Works, 5. Regional Directorate, 56. Division Office, 71450, Kırıkkale, Turkey. E-mail address: halukbali51@gmail.com.tr 
classical measurement methods, satellite techniques, laser scanning, radar interferometry, etc. Geotechnical methods are divided into two as physical and geometric measurements. Physical measurements include pore water pressure measurements, stress, strain measurements, etc., geometrical measurements are slope measurements, displacement measurements, determination of horizontal / vertical movements, crack- joint measurements, etc. [1].

In this study, important dams built in our country and their details are given. In addition, the dams where monitoring studies are conducted and the methods they are monitored are explained.

\section{Important Dams Built In Our Country}

Çubuk Dam: It is the first dam of our country, which was built between 1930-1936 for water supply and flood protection. It was built in the concrete gravity type [2].

Sarıyar Dam: It is our first big hydroelectric power plant project built between 1950-1956 [2].

Elmalı Dam: The first and only buttress dam of our country, Elmalı Dam was built between 1952-1955 for the purpose of water supply [3].

Gökçekaya Dam: Turkey's first concrete arch dam and it was built between the years 1967-1972 for hydroelectric power generation [2].

Keban Dam: The first large dam experience of our country was built between 1965 and 1974 in composite type (concrete gravity and rock fill). Its height is $210 \mathrm{~m}$ from thalweg and the lake area in the normal water level is $675 \mathrm{~km}^{2}$. It has the largest artificial lake after Ataturk Dam [2].

Karakaya Dam: It is the second biggest dam of our country with its installed capacity of 1800 MW (Megawatt). It was built in the concrete arch type between 1976-1987 [2].

Oymapinar Dam: It was built in the double arched concrete arch type between 1977-1984. It is $185 \mathrm{~m}$ high from the foundation. It has the largest karst spring in the world, boiling from one eye, with an average flow rate of $50 \mathrm{~m}^{3} / \mathrm{h}[4]$.

Atatürk Dam: It is the largest dam of our country with its installed capacity of $2400 \mathrm{MW}$ and body volume of 84,5 milyon $\mathrm{m}^{3}$. It was built clay core rock fill type between 1983-1992. The lake area is $817 \mathrm{~km} 2$ and its height from the foundation is $169 \mathrm{~m} \mathrm{[2].}$

Kürtün Dam: It is the first concrete faced rockfill dam of our country and it was built between 1986-2002 for energy production [5].

Muratl1 Dam: It is the first asphalt faced rockfill dam of our country and it was built between 1999-2005 to produce energy and flood protection [6].

Ermenek Dam: It is the second highest dam in Turkey with a height of $218 \mathrm{~m}$ from thalweg level. 
It is a double-curvature concrete arch dam, completed in 2009 [2].

Çine Adnan Menderes Dam: It was built between 1995-2010 in the form of a roller compacted concrete dam type. The dam stands out with its irrigation and flood protection feature [2].

Deriner Dam: The dam, which was built between 1998 and 2012 in the form of a doublecurvature concrete arch dam, is the highest dam in our country with a height of $249 \mathrm{~m}$ from the foundation [2].

Yukarı Kaleköy Dam: The dam, which received the best project award at the 8th International Symposium on RCC dams, was completed in 2018 [7].

Yusufeli Dam: The dam, the construction of which started in 2012, will become the highest dam of our country with a height of $275 \mathrm{~m}$ from the foundation. [2].

Reyhanlı Dam: It has the longest crest length $(9271 \mathrm{~m})$ in our country, was built in clay core sand-gravel filling type [8].

According to the International Commission on Large Dams (ICOLD) data, updated in September 2019, our 973 dams evaluated in the large dams category. In the concrete gravity dam category, Keban Dam is 12th with a height of $207 \mathrm{~m}$ and Boyabat Dam is 16th with a height of $195 \mathrm{~m}$. In the concrete arch dam category, Yusufeli Dam is 7th with $270 \mathrm{~m}$ and Deriner Dam is 10th with $249 \mathrm{~m}$ height. In addition, Yusufeli Dam is 13th with $270 \mathrm{~m}$ in the list of heights of all dam types. According to the ranking made by irrigation areas, Atatürk Dam is in the $12^{\text {th }}$ rank [9].

In Table 1, the most important dams of our country in terms of body volume, installed power and height are given [8]. 
Table 1. The ranking of our dams by volume, installed power and height [8]

\begin{tabular}{|c|c|c|c|c|c|c|c|c|c|c|c|}
\hline \multicolumn{4}{|c|}{ Ranking by Volume } & \multicolumn{4}{|c|}{ Ranking by Installed Power } & \multicolumn{4}{|c|}{ Ranking by Height } \\
\hline $\begin{array}{l}\text { Dam } \\
\text { Name }\end{array}$ & Year & $\begin{array}{l}\text { Dam } \\
\text { Type }\end{array}$ & $\begin{array}{c}\text { Dam } \\
\text { Volume } \\
\left(\times 10^{3}\right. \\
\left.\mathrm{m}^{3}\right)\end{array}$ & $\begin{array}{l}\text { Dam } \\
\text { Name }\end{array}$ & Year & $\begin{array}{l}\text { Dam } \\
\text { Type }\end{array}$ & $\begin{array}{l}\text { Installed } \\
\text { Capacity } \\
\text { (MW) }\end{array}$ & $\begin{array}{l}\text { Dam } \\
\text { Name }\end{array}$ & Year & $\begin{array}{l}\text { Dam } \\
\text { Type }\end{array}$ & $\begin{array}{l}\text { Height } \\
\text { (m) }\end{array}$ \\
\hline Atatürk & 官 & CCR & 84.500 & Atatürk & ర্ঠ & $\mathrm{CCR}$ & 2.400 & Yusufeli & ' & DCCA & 275,0 \\
\hline Ilisu & $\underset{\infty}{\stackrel{N}{\infty}}$ & CFR & 24.100 & Karakaya & $\vec{b}$ & $\mathrm{AD}$ & 1.800 & Deriner & $\underset{\substack{N \\
O}}{\stackrel{D}{D}}$ & DCCA & 249,0 \\
\hline Kiğ 1 & \begin{tabular}{l}
\multirow{2}{0}{} \\
$a$
\end{tabular} & CCR & 22.500 & Keban & $\begin{array}{l}\overrightarrow{0} \\
\vec{u} \\
\text { u }\end{array}$ & $\mathrm{CCR}$ & 1.330 & Ermenek & 8 & DCCA & 218,0 \\
\hline Reyhanlı & & $\mathrm{CCH}$ & 18.475 & Ilisu & $\underset{\infty}{\stackrel{N}{O}}$ & CFR & 1.200 & Keban & $\begin{array}{l}\overrightarrow{0} \\
u \\
u\end{array}$ & CCR & 207,0 \\
\hline Çatalan & ஜ & CFR & 17.000 & Altınkaya & $\begin{array}{l}\vec{b} \\
\infty \\
\infty\end{array}$ & $\mathrm{CCR}$ & 703 & Berke & 管 & DCCA & 201,0 \\
\hline Alkumru & $\stackrel{N}{\mathscr{O}}$ & CCR & 16.275 & $\begin{array}{l}\text { Birecik- } \\
\text { Nizip }\end{array}$ & $\frac{1}{8}$ & CCR & 672 & Altınkaya & $\begin{array}{l}\vec{b} \\
\infty \\
\infty\end{array}$ & $\mathrm{CCR}$ & 195,0 \\
\hline Altınkaya & $\begin{array}{l}\bar{\varnothing} \\
\infty \\
\infty\end{array}$ & CCR & 15.920 & Deriner & $\underset{N}{\stackrel{N}{O}}$ & DCCA & 670 & Boyabat & $\stackrel{N}{O}$ & CG & 195,0 \\
\hline Keban & $\begin{array}{l}\vec{\sigma} \\
u \\
\end{array}$ & CCR & 15.585 & $\begin{array}{c}\text { Yukarı } \\
\text { Kaleköy }\end{array}$ & 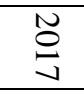 & $\mathrm{RCC}$ & 627 & Oymapınar & $\begin{array}{l}\vec{b} \\
\infty \\
\perp\end{array}$ & DCCA & 185,0 \\
\hline Kralkızı & $\underset{\nabla}{\nabla}$ & CCR & 15.170 & Beyhan 1 & $\begin{array}{l}\text { No } \\
\text { Un }\end{array}$ & $\mathrm{RCC}$ & 582 & Artvin & $\begin{array}{r}N \\
\text { O } \\
\text { Un }\end{array}$ & $\mathrm{CG}$ & 180,0 \\
\hline Özlüce & $\overrightarrow{8}$ & CCR & 14.600 & Yusufeli & ' & DCCA & 558 & Silvan & & CFR & 175,5 \\
\hline
\end{tabular}

Note: CG-Concrete Gravity, AD-Arch Dam, DCCA-Double Curvature Concrete Arch, CCH-Clay Core Homogeneous Fill, CCR-Clay Core Rockfill, CFR-Concrete Faced Rockfill, RCC-Roller Compacted Concrete.

\section{Dam Monitoring In Our Country}

Dams are exposed to various loads and effects during the construction, first filling period and operational life. These loads are dead load, normal water load, flood load, uplift pressure, seepage load, silt and sediment load, ice load, earthquake load, lower atmospheric pressure, wave pressure, rapid drawdown of the reservoir, steady flow condition, etc. Particularly for the concrete dams thermal load is also important [1, 10, 11 and 12].

By the construction of large dams in our country, more attention has been given to monitoring studies in recent years. Monitoring studies in our dams are performed using geodetic or geotechnical methods. The details of the monitoring works carried out in our important dams are given below.

Monitoring of Altınkaya dam (Figure 1) was carried out by geodetic methods. The evaluation process was based on comparing the obtained geodetic results with the values obtained by the finite element method [13 and 14]. 


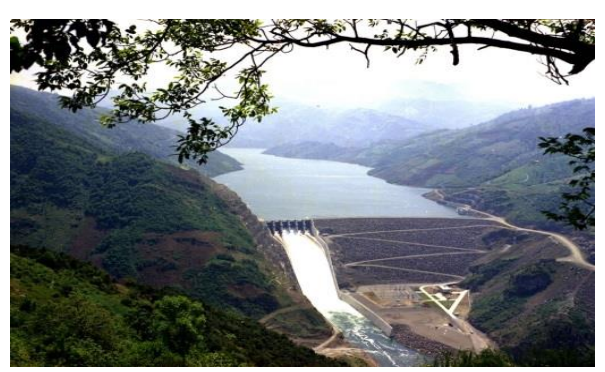

Figure 1. Altınkaya Dam in Samsun [15]

Deformation monitoring studies in Oymapinar Dam were carried out using geodetic methods [16 and 17] (Figure 2).

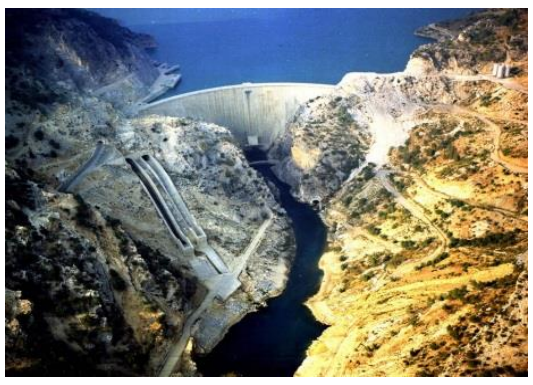

Figure 2. Oymapınar Dam in Antalya [15]

Horizontal and vertical movements in Dicle Dam (Figure 3) were monitored using geodetic methods. Deformation analysis was carried out using the $\mathrm{S}$ transformation method [18].

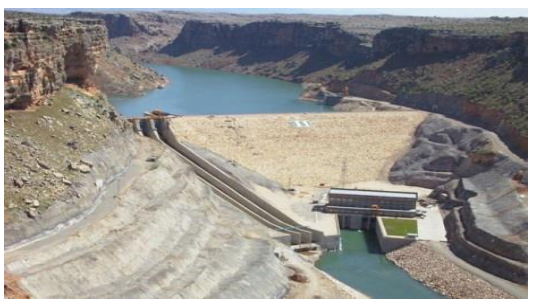

Figure 3. Dicle Dam in Diyarbakır [19]

The monitoring studies in Atatürk dam (Figure 4) include geodetic methods. Among these methods, GPS and classical measurement methods were used [20, 21 and 22]. 


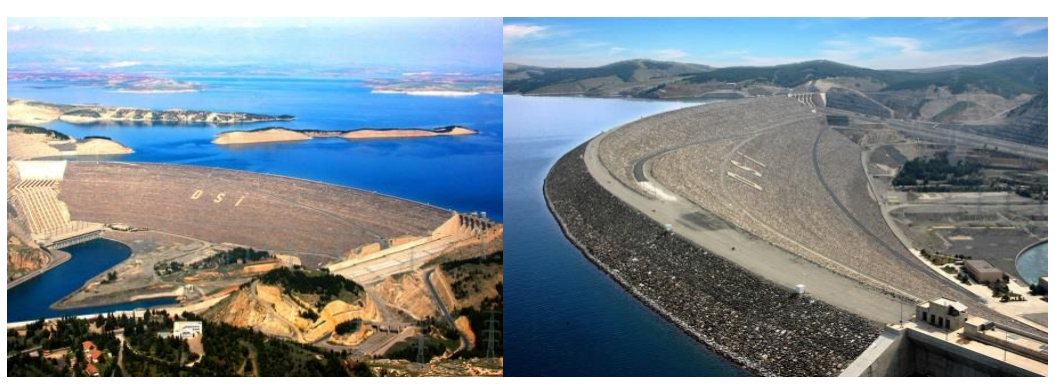

Figure 4. Atatürk Dam in Adıyaman / Şanlıurfa [15]

In Pamukçay Dam (Figure 5), leakage and settlement analyzes were carried out using finite element method and the results obtained were compared with pore water pressure and deformation measurement values from geotechnical methods [23 and 24].

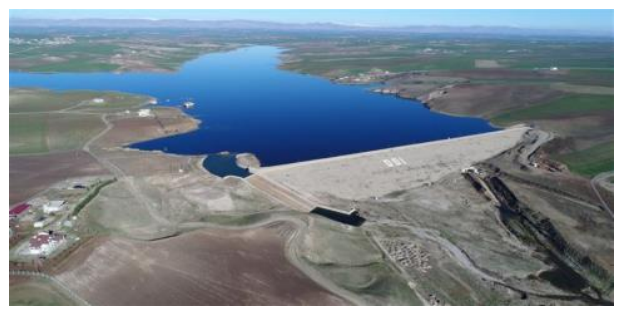

Figure 5. Pamukçay Dam in Diyarbakır [25]

Geodetic methods were used to determine horizontal and vertical movements in Obruk Dam (Figure 6). GNSS and classical methods were used to determine the horizontal movements and precise leveling technique were to determine the vertical movements [26 and 27].

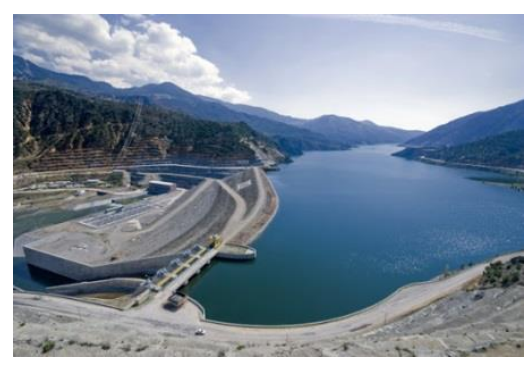

Figure 6. Obruk Dam in Çorum [28]

The monitoring studies carried out in the second highest dam in Turkey, Deriner, include geodetic methods (Figure 7). In the studies, besides the classical measurements, GNSS technique was used [29, 30 and 31]. 


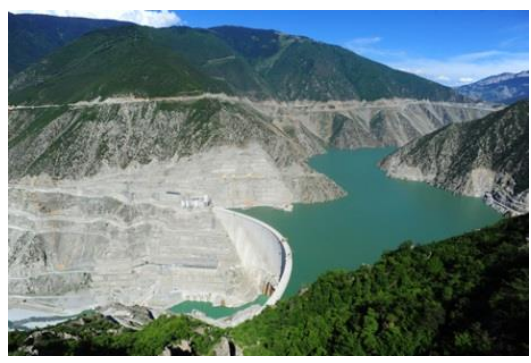

Figure 7. Deriner Dam in Artvin [2]

Ermenek dam is the third highest dam in Turkey (Figure 8). Both geodetic and geotechnical methods have been used to determine possible deformations in this dam. Periodic measurements were carried out by establishing a microgeodetic network to determine horizontal deformations. Precise leveling technique was used to determine vertical movements. Data of geotechnical measuring instruments (pendulum, extensometer, inclinometer, clinometer, load cell, joint meter, piezometer) were also examined. In this dam, geodetic and geotechnical data were evaluated together and possible movements in the dam were analyzed comprehensively [1, 32 and 33].

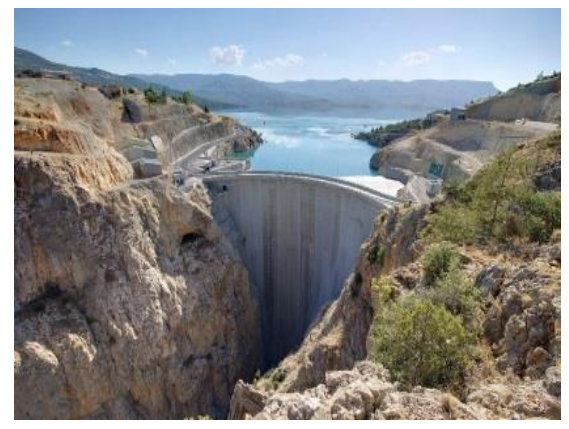

Figure 8. Ermenek Dam in Karaman [8]

\section{Results}

The loads affecting the dams never disappear. For this reason, dams must be monitored before construction, during construction, first filling and the whole operational life. Many dams have been built in our country and very few of them are regularly monitored. When we look at dam monitoring studies in our country, we see that mostly geodetic methods are used. Geodetic and geotechnical methods have advantages and disadvantages against each other in monitoring the movements in our dams. While surface deformations can be determined by geodetic methods, sub-surface deformations can also be determined by geotechnical methods. In addition, important parameters such as concrete temperature, load changes, slope changes, joint openingclosing values, stress values, settlement, displacement, seismic acceleration, flow rate, and pore water pressure values can be determined by geotechnical methods. However, while only relative deformations can be determined by geotechnical methods, both absolute and relative deformations are determined by geodetic methods. 
In order to monitor the dam comprehensively, it is necessary to take advantage of both methods. For this purpose, it is important to use the two methods to test and complement each other. It is seen that a comprehensive deformation monitoring study was carried out in Ermenek dam by using the data of two methods. In our large dams to be built in the future, it is important to use both methods instead of a single method in order to interpret the obtained results more accurately.

\section{Conclusions}

Correct interpretation is as important as obtaining correct results in dam monitoring studies. Our dams must be continuously monitored in order to prevent possible dam accidents and to prevent loss of life and property. Besides the deformation determination, dam monitoring has early warning feature. In this study, the methods used are explained for dam monitoring in Turkey. Monitoring studies mostly include geodetic or geotechnical methods. It is important to use the geodetic and geotechnical methods together to ensure the safety of the Yusufeli, Silvan and Söylemez dams built with great expenditures and the dams to be built in the future. In addition, dam monitoring works should be supported with legislation such as law and regulation in terms of continuity.

\section{References}

[1] Alcay S. Deformation monitoring using geodetic and geotechnical methods on concrete arch dams and example of Ermenek dam. Ph.D Thesis, The Graduate School of Natural and Applied Science of Selcuk University, Konya, 2014.

[2] http://bilgi.dsi.gov.tr/sudunyasi/158/files/assets/basic-html/index.html\#1

[3] https://tr.wikipedia.org/wiki/Elmal\%C4\%B1-2_Baraj\%C4\%B1

[4] Ozis U. and Yanar H. Oymapınar Dam and hydroelectric power plant. 4th water structures symposium, The Union of Turkish Engineers and Architects, Chamber of Civil Engineers, Antalya, 2015; 22-31.

[5] http://www.suyapi.com.tr/tr/38011/Kurtun-Baraji-ve-HES

[6] http://temelsu.net/muratli-baraji-ve-hidroelektrik-santrali-uygulama-projesi-ve-insaat musavirlik-hizmetleri/

[7] http://www.dsi.gov.tr/haberler/2019/11/14/bing\%C3\%B6l-yukar\%C4\%B1kalek\%C3\%B6y-baraj\%C4\%B1-\%C3\%A7in-de-'en-i-yi-proje$\% \mathrm{C} 3 \% \mathrm{~B} 6 \mathrm{~d} \% \mathrm{C} 3 \% \mathrm{BCl} \% \mathrm{C} 3 \% \mathrm{BCn} \% \mathrm{C} 3 \% \mathrm{BC}-$ ald $\% \mathrm{C} 4 \% \mathrm{~B} 1$

[8] http://bilgi.dsi.gov.tr/dijital/suvedsi/files/assets/basic-html/index.html\#1 
[9] https://www.icold-cigb.org/article/GB/world_register/general_synthesis/classification-bytype

[10] https://www.ferc.gov/sites/default/files/2020-04/chap4.pdf

[11] https://www.publications.usace.army.mil/Portals/76/Publications/EngineerManuals/ EM_1110-2-2200.pdf

[12] https://www.publications.usace.army.mil/Portals/76/Publications/EngineerManuals/ EM_1110-2-2201.pdf

[13] Tasci L., Yildirim B. and Gokalp E. Determination of the deformation by geodetic and finite element methods at rock fill dam. Firat University Journal of Science and Engineering Sciences, 2004; 16(2): 205-219.

[14] Gokalp E. and Tasci L. Deformation monitoring by GPS at embankment dams and deformation analysis. Survey Review, 2009,;41(311):86-102 .

[15] http://www.dsi.gov.tr/dsi-galeri/barajlar

[16] Demirkaya S. Physical interpretation of the horizontal displacements in an arch dam. The Union of Turkish Engineers and Architects, Chamber of Survey and Cadastral Engineers, 10. Turkey Scientific and Technical Conference, 2005, Ankara.

[17] Erkaya H., Hosbas R.G., Gulal V.E., Ersoy N., Dogan U., Pırtı A., Soycan M., Gumus K., Ocalan T., Aykut N.O., Akpınar B. and Poyraz F. Determination of deformations in concrete arch dams by modern measurement techniques. The Union of Turkish Engineers and Architects, Chamber of Survey and Cadastral Engineers, 12. Turkey Scientific and Technical Conference, 2009, Ankara.

[18] Cakir S. Determination of engineering construction deformations by $\mathrm{S}$ transformation and aplication. Master Thesis, Graduate School of Natural and Applied Sciences, Department of Geodesy and Photogrammetry, 2006, Konya.

[19] http://www.dsi.gov.tr/haberler/2012/12/03/kralkizidiclesulamasiilebereketgeliyor

[20] Kalin G. Clay core rock fill dams with geodetic method deformation measurements: Ataturk dam example. ITU Institute of Science and Technology, Master Thesis, 2010, Istanbul.

[21] Kalkan Y. Dam safety and deformation monitoring studies in Ataturk dam. Electronic Journal of Map Technologies, 2014; 6(3):40-50. 
[22] Yavasoglu H.H., Kalkan Y., Tiryakioglu I., Yigit C.O., Ozbey V., Alkan M. N., Bilgi S. and Alkan R. M. Monitoring the deformation and strain analysis on the Ataturk dam. Turkey, Geomatics, Natural Hazards and Risk, 2018; 9(1): 94-107.

[23] Oral I.H. Measurement values of Pamukcay dam comparison with analysis. Department of Civil Engineering, Institute of Natural and Applied Sciences, University of Dicle, Master Thesis, 2016, Diyarbakir.

[24] Taskiran T. and Oral I.H. A Comparative study between measured values of displacement/pore water pressures with finite element analysis results of Pamukcay dam. 7th Geotechnical Symposium, The Union of Turkish Engineers and Architects, Chamber of Civil Engineers, 2017; 247-256.

[25] http://dsi.gov.tr/haberler/2018/03/16/diyarbak\%C4\%B1r-da-\%C3\%BClkemizin-i-kinci b\%C3\%BCy\%C3\%BCk-sulama-baraj\%C4\%B1n\%C4\%B1-yap\%C4\%B1yoruz

[26] Alkan R. M., Gulal V. E., Ilci V., Ozulu I. M., Alkan M. N., Kose Z. K, Aladogan K., Tombus F. E., Sahin M., Yavasoglu H. and Oku G. Obruk Dam deformation measurements. Chamber of Survey and Cadastral Engineers, 8th National Engineering Measurements Symposium, Y1ldiz Technical University, 2016, İstanbul.

[27] Kose, Z. Determination of vertical deformations in Obruk dam By precise leveling method. Afyon Kocatepe University Graduate School of Natural and Applied Sciences Department of Geomatics Engineering, Master Thesis, 2018.

[28] http://www.dsi.gov.tr/haberler/2016/03/02/obrukdutluderesulamasi

[29] Konakoglu B. ve Gokalp E. Vertical deformation measurements starting from the first filling: a case study of the deriner dam. International Conference on Advanced Engineering Tecnologies, 2017, Bayburt.

[30] Konakoglu B. ve Gokalp E. Deformation measurements and analysis with robust methods a case study Deriner Dam, Turkish Journal of Science \& Technology, 2018; 13: 99-103,

[31] Konakoglu, B., Cakir L. and Yilmaz V. Monitoring the deformation of a concrete dam: a case study on the Deriner Dam. Geomatics, Natural Hazards and Risk, 2020; 11(1): 160177.

[32] Yigit C.O., Alçay S. and Ceylan A., 2016, Displacement response of a concrete arch dam to seasonal temperature fluctuations and reservoir level rise during the first filling period: evidence from geodetic data. Geomatics, Natural Hazards and Risk, 2016; 7(4): 1489-1505.

[33] Alcay S., Yigit C.O., Inal C. and Ceylan A. Analysis of displacement response of the Ermenek dam monitored by an integrated Geodetic and Pendulum System, International Journal of Civil Engineering, 2018; 16(10): 1279-1291. 